\title{
What is so theological about a faculty of theology at a public university? Athens - Berlin - Pretoria
}

\begin{tabular}{|c|c|}
\hline $\begin{array}{l}\text { Author: } \\
\text { Johan Buitenc }\end{array}$ & \\
\hline $\begin{array}{l}\text { Affiliation: } \\
\text { Department } \\
\text { Systematic Th } \\
\text { of Theology, U } \\
\text { Pretoria, Pretc }\end{array}$ & $\begin{array}{l}\text { f Historical and } \\
\text { ology, Faculty } \\
\text { niversity of } \\
\text { ria, South Africa }\end{array}$ \\
\hline $\begin{array}{l}\text { Research Proj } \\
\text { Project Leade } \\
\text { Project Numb }\end{array}$ & $\begin{array}{l}\text { ct Registration: } \\
\text { r: J. Buitendag } \\
\text { er: } 02402343\end{array}$ \\
\hline $\begin{array}{l}\text { Description: } \\
\text { This research } \\
\text { project, 'Univ } \\
\text { and Theology' } \\
\text { Prof. Dr Johan } \\
\text { Department o } \\
\text { Systematic Th } \\
\text { of Theology, L } \\
\text { Pretoria. }\end{array}$ & $\begin{array}{l}\text { s part of the } \\
\text { rsity, Education } \\
\text { directed by } \\
\text { Buitendag, } \\
\text { f Historical and } \\
\text { eology, Faculty } \\
\text { niversity of }\end{array}$ \\
\hline $\begin{array}{l}\text { Correspondin } \\
\text { Johan Buitend } \\
\text { 1jbuiten@gm }\end{array}$ & $\begin{array}{l}\text { g author: } \\
\text { ag, } \\
\text { ail.com }\end{array}$ \\
\hline $\begin{array}{l}\text { Dates: } \\
\text { Received: } 02 \\
\text { Accepted: } 17 \\
\text { Published: } 18\end{array}$ & $\begin{array}{l}\text { pr. } 2019 \\
\text { Apr. } 2019 \\
\text { June } 2019\end{array}$ \\
\hline $\begin{array}{l}\text { How to cite th } \\
\text { Buitendag, J., } \\
\text { so theological } \\
\text { of theology at } \\
\text { university? At } \\
\text { Pretoria', HTS } \\
\text { Studies/Theol } \\
75(4) \text {, a5488. } \\
10.4102 / \text { hts.v }\end{array}$ & $\begin{array}{l}\text { is article: } \\
\text { 2019, 'What is } \\
\text { about a faculty } \\
\text { a public } \\
\text { nens - Berlin- } \\
\text { Teologiese } \\
\text { gical Studies } \\
\text { https://doi.org/ } \\
75 i 4.5488\end{array}$ \\
\hline $\begin{array}{l}\text { Copyright: } \\
\text { (c) 2019. The A } \\
\text { Licensee: AOS } \\
\text { is licensed unc } \\
\text { Creative Comr } \\
\text { Attribution Lic }\end{array}$ & $\begin{array}{l}\text { Iuthors. } \\
\text { IS. This work } \\
\text { der the } \\
\text { nons } \\
\text { ense. }\end{array}$ \\
\hline Read online: & \\
\hline 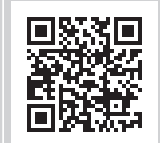 & $\begin{array}{l}\text { Scan this QR } \\
\text { code with your } \\
\text { smart phone or } \\
\text { mobile device } \\
\text { to read online. }\end{array}$ \\
\hline
\end{tabular}

In this article, the author engages with the question 'what is so theological about theological education?', which he calls a genealogy of theology. This matter is approached from a very specific vantage point as the author was the former dean of the Faculty of Theology and Religion at the University of Pretoria (South Africa) and has engaged in this research project over the past 5 years, as the Faculty was under severe review as to its composition, and ultimately its very future. This article endeavours to bring to the surface the underlying theology of the author and the paradigm he is operating from. It concludes with a definition of theology as he sees it, but with the explicit qualification of it being situated at a researchintensive university competing for a notable position on the ranking indexes of world universities. A new niche is thus opening up for theology (vis-à-vis a seminary or even a Christian university), namely, a 'scholarly endeavour of believers in the public sphere in order to inquire into a multi-dimensional reality in a manner that matters'.

Keywords: Theological education; Metareality; Critical realism; Society; Faith communities; Ecodomy; Transformation; decolonisation; Luhmann; Bhaskar; QS World Ranking of Universities; University of Pretoria; Moltmann

\section{Introduction}

This article is the conclusion of a series of publications about the question raised in the title. In a recent article, I dealt with what I regard as genetically part of a theological inquiry as a scientific discipline at a research-intensive public university. Obviously, it would be very subjective, but as the former dean of the Faculty of Theology and Religion (2010-2018) at the University of Pretoria, I have felt obliged to delineate the theological paradigm I am working from and the understanding and intention I had of the vision and mission of the Faculty.

Theology, to me, is about the creation and the Creator, or more correctly, an attempt to be a responsible discourse partner in the public domain in the human being's search for meaning and comprehensiveness. I am of the conviction that theology can contribute to this enterprise. Theology has a distinctive yet responsible epistemology. The inquiry is indeed not without presuppositions, but at least it has a rational and an accountable claim.

In this article, the emphasis is not on (my understanding of) theology as such, but how I understand the role of theology at a public university in Africa competing for a favourable position on the world ranking indices. It is my conviction that this new understanding of what a university is all about presents theology with a major challenge and that a new node of scientific theology, without any form of heteronomy, should be pursued. As a case study, I use the Faculty of Theology and Religion at the University of Pretoria. Certain aspects of the Faculty's current composition need clarification, which is precisely the aim of this article.

The Faculty underwent a sincere restructuring process (2013-2016) and not only was the name of the Faculty changed to the Faculty of Theology and Religion, but two departments have merged ${ }^{1}$ and one department changed ontologically to the Department of Religion Studies. At least two aspects are remarkable: firstly, the Department of Old Testament Studies and the Department of New Testament Studies have not merged, as is the case in many restructuring processes at other similar faculties. Secondly, the Department of Religion Studies (not Religious Studies)2 continues to accommodate the discipline of Missiology as part of it, giving Christianity a very distinct position.

\section{The Department of Dogmatics and Christian Ethics and the Department of Church History and Church Polity.}

2.Ninian Smart states emphatically that 'religious studies' is empirical, descriptive, explanatory and methodologically agnostic (Fasching 2002:155). Religion is rooted in a faith community. See also Farley (1988:57) and Tanner (2002:209) on this topic. 
Despite the fact that all these changes were discussed at length at several lekgotlas ${ }^{3}$ of the Faculty, and subsequently proposed to and approved by the Senate, the rationale of these 'inconsistencies' has not been assessed so far.

Knowledge is not mere information and technique, but rather an understanding entailing experience and contemplation. Metareality (note the omission of definite article) ${ }^{4}$ is beyond what our senses can grasp. It goes beyond modernity, modernism and even post-modernism, that is, a sublime discourse on the nature of the self. Spirituality is ubiquitous and transcends binaries of fact and value, materialism and idealism, seen and unseen.

My thesis is that theology (in particular at a public university) has to shift beyond the current thinking and move from actualities to potentialities, from inter-disciplinarily to transdisciplinary, from critical realism to meta-critical realism, from post-theism to meta-theism, and from autonomy and heteronomy to theonomy, ${ }^{5}$ where Theos is understood as 'deeply embedded in human brains and bodies, on the basis of which culture is built and treasured' (Bowker 2003:31).

Theonomy is not about Theos as a dogmatic concept, but about the experienced demand for self-transcendence, or the 'consciousness of being absolutely dependent' (Schleiermacher 1999:12), or the 'ultimate concern' (Tillich 1946:82). In a previous publication, I applied the threefold hermeneutical key of mimesis of Paul Ricoeur (Buitendag 2014), while in this article I imagine a wider horizon opening up: pre-critical naiveté that becomes critical inquiry and which in turn opens up a vision for meta-critical reflection. This will be revealed as the theses of the articles unfold. I use the term 'archaeology' to reflect on some historical building blocks and the word 'genealogy' (as has been pointed out) to acknowledge 'knowledge in the blood' (Jansen 2009) or the DNA of theological inquiry.

Milbank (2013:19) argues that theology is concerned with 'being in its entirety in relation to God', which has the implication that philosophy should be part of the discourse of what theology is (cf. Farley 1988:118). Philosophy is the science of being as such (ontology) and how that can be known (epistemology). This does not make theology subservient to philosophy, but it influences our understanding of what theology is all about. It is, however, interesting that Milbank (2013:13) asserts that 'theology is to the entire understanding of reality', exactly what I argued in previous articles. $^{6}$

\footnotetext{
3.Workshops.

4.The reader will note that in many cases, I avoid using both the definite and the indefinite articles. I do this in order not to choose between singular and plural and to keep it open. The same would apply to nouns like theology, science and epistemology. I prefer to spell theology in the lower case for the very same reason.

5.I owe much to Paul Tillich in this regard. The following citation of Tillich is a good summary of his understanding of theonomy: "The words "autonomy", "heteronomy" and "theonomy" answer the question as to where the "nomos" or law of life is and "theonomy" answer the question as to where the "nomos" "or law of life is rooted ... A theonomous culture expresses in its creations an ultimate concern and a transcending meaning not as something strange but as its own spiritual ground. "Religion is the substance of culture and culture the form of religion." This was the
most precise statement of theonomy' (Tillich 1946:80).

6.Alston (1991:2) acknowledges that the existence of God is axiomatic in this epistemology and prefers to speak rather of 'epistemic justification'.
}

The notion of 'decolonisation' obviously forms an integral part of this debate about what a university is because a Eurocentric canon produces a Western way of seeing truth and disregards other knowledge traditions. ${ }^{7}$ The Western paradigms should be deconstructed and new models of knowledge are developed. Heleta (2016) argues that:

South Africa must tackle and dismantle the epistemic violence and hegemony of Eurocentrism, completely rethink, reframe and reconstruct the curriculum and place South Africa, Southern Africa and Africa at the centre of teaching, learning and research. (p. 1)

I have clearly expressed my conviction that theology has a place in a public university today, and not only should theology be redefined, but also the nature of a university as such should be rethought, especially in the 21st century.

\section{University and theology}

David Kelsey is one of the current champions of research about the roots of the Western academy and theology and set the agenda by means of a typology in using Athens and Berlin as the two main models to categorise academy and theology (Kelsey 1992, 1993). He does this comparison both diachronically and synchronically and comes up with a third option, of bringing unity and pluralism dialectically together. $\mathrm{He}$ is therefore of the opinion that the theological schools in North America are ineluctably located between Athens and Berlin (Kelsey 1993:6). Ford follows him in this and uses the same archaeology of theological education, but adds his home university, Cambridge, as a case study (Ford 2007:304316). I will do the same, but (as indicated) engage Pretoria as being the locus of my thinking.

The clue to the Athens model is the Greek concept of paideia, meaning the process of cultivating the soul and developing character formation (Kelsey 1993:6). In ancient Athens, this had the aim of forming young men by those virtues appropriate to society in order to function as responsible adults. Kelsey (1993:7) points out that the whole person was involved, the body to physical discipline and the soul to ancient Greek tradition and literature. Contemplation, as mentioned, was a way of understanding. There are two ways of understanding (Kelsey 1992:35-36): guiding human action (practical understanding) and making things (productive understanding). Contemplation is unchangeable and practical understanding is contingent.

Christians, says Kelsey, brought a third definite mark to contemplation: paideia purports to promote wisdom and personal knowledge of God. Understanding God will bring happiness. This makes studying the Bible and meditation inevitable. Augustine was interpreted to see 'action' as done for the neighbour's well-being. Scientia and sapientia were intertwined. Understanding God is, therefore, a path or journey through different stages in order to grasp God. This, of course, could be seen as a form of reification of God.

7.See the excellent book about transforming theological knowledge edited by Venter and Tolmie, published in 2012. 
This has set the scene for theological education, as Kelsey (1992) states:

The understanding of God that is the aim of theological schooling is basically understanding by way of discursive reasoning. It is done in faith and done as a way of loving God. It is a way of Christian life to which acts of neighbor love are integral but subordinate. (p. 41)

It should be emphasised that this journey of understanding God leads to a comprehensive interpretation of reality. This indeed is reminiscent of Newman's understanding of knowledge. Kelsey sees Newman's thought as the mid-19th century's version of the Athens model because he draws a clear line between teaching theology as part of 'professional' education and cultivating human intellectual capacities as a goal in itself (Kelsey 1993:37). This is already some sort of a hybrid, as the Berlin model will manifest. Ford (2007) gives a very apt summary of the classic university:

first understanding and truth for their own sake; second, formation in a way of life, its habits and virtues; and third, utility in society - study oriented towards practical use an employment in various spheres of life. (p. 308)

A faculty of theology was part of the University of Berlin since its inception in 1810. The Berlin model connects both Wissenschaft as critical research and professional training for ministry. As a research university, the question of the position of theology was a burning one. Kelsey (1993:13-15) sums it up by stating that the overarching goal was to do research and teach students to do research; it had to inquire about the truth whatever subject was studied. Inquiry is clearly critical at a research university and very much disciplined. The third important trait of Wissenschaft is that it should protect academic freedom.

It could be argued that theology betrays the ideals of a proper critical research university. Schleiermacher drafted the provisional statutes for the new university in Berlin and subsequently introduced a second pole to the Berlin model: professional education. Faculties like Medicine, Law and Theology contribute to the well-being of society as a whole with regard to health, order and morals. Schleiermacher agreed that theology is not a pure science as it rests on a kind of experience that can be the subject of philosophical inquiry (Kelsey 1993:17). Theology has thus a place in this model as long as it maintains the interdependence between Wissenschaft and professional education.

Richard Niebuhr is a later exponent of the Berlin model. The question that he grappled with in his book, The Purpose of the Church and Its Ministry (1956), was what makes a professional school 'professional'. In Chapter 3, 'The Idea of a Theological School', they (Niebuhr, Williams \& Gustafson 1956) ${ }^{8}$ write:

We have, indeed, found in the schools evidence of that pluralism and harassment; for they reflect in the multiplicity of their numbers, the variety of their statements of purpose and the

8. Seeing that this is an electronic book, no page numbers are provided. https:///www religion-online.org/book-chapter/chapter-3-the-idea-of-a-theological-school/ (Retrieved on 07 March 2019). conglomerate character of their courses of study the lack of unity symptomatic of their social context.

Niebuhr differs from Schleiermacher in that training is indispensable to the church, but not to society as a whole (Kelsey 1993:72). The purpose of the church is therefore the primary focus of professional training. In the end, it is about understanding God (i.e. experience and contemplation) and God's relation to the church:

But theology is differentiated from other kinds of intellectual activity by being the reflection that goes on in the Church; it is therefore the kind of thinking that is directed toward God and man-before-God as its objects and which is guided by the love of God and neighbor. (Niebuhr et al. 1956)

Kelsey (1993:74) criticises this because 'theological schooling is thrown into self-contradiction' if it serves itself and wants to increase its numbers. 'Professional' has changed from what the Berlin model had in mind, as it is functionalist and individualistic (Kelsey 1992:94).

Niebuhr substitutes Christology for Theology but, as Kelsey (1993:77) says, only in the 'intellectual mode'. Niebuhr et al. $(1956)^{9}$ state subsequently:

As center of the Church's intellectual activity, animated by the Church's motivation and directed by its purpose, the theological school is charged with a double function. On the one hand it is that place or occasion where the Church exercises its intellectual love of God and neighbor; on the other hand it is the community that serves the Church's other activities by bringing reflection and criticism to bear on worship, preaching, teaching and the care of souls.

To sum up, the Athens model is a personal journey from revelation to appropriation, with the focus on the believing subject as the vehicle to serve the community. It is about discernment, meditation and practical wisdom. Yet it is intensely inward and private (Kelsey 1993:21). Over and against this, the Berlin model is a movement from data to theory to application. Perhaps the concepts of deductive and inductive reasoning describe the differences adequately. The Berlin model of theological education has the church in mind, while the Athens model has a theocentric focus. ${ }^{10}$ In their respective extreme forms, they could lead to the difference between ecclesiastical heteronomy and personal autonomy.

It is clear that the Pretoria model is a hybrid. I wrote extensively about the history and nature of the Faculty in the articles mentioned earlier. The reason for this hybrid model is twofold. Firstly, it had a history of two different denominational traditions where the primary difference, in my view, manifested in the option between the ordo duplex and the ordo simplex with all their

9.https://www.religion-online.org/book-chapter/chapter-3-the-idea-of-atheological-school/

10.It is rather interesting that never has the question been raised that if a faculty of theology should dissolve, a Faculty of Education could rather be the more appropriate locus for theology, keeping in mind the other pole of the Berlin model: professional education. In all the cases where faculties of theology were dissolved (at least in South Africa), the obvious faculty for theology to merge into was (at least in South Africa), the obvious faculty for theology to merge into was
Humanities. The Berlin model would definitely be more comfortable to see a department of theology in Education rather than in Humanities. 
corollaries $^{11}$ (Buitendag 2016:9). These options determine the understanding of spiritual formation, specifically critical science and the role of the church. I argued that although the Dutch Reformed Church (DRC) explicitly opted for an ordo simplex and the Netherdutch Reformed Church (NDRC) opted for an ordo duplex, the distinctions blurred in both cases, especially because of interventions by the churches' leadership at the time. I do contend, however, that the tradition of the DRC is closer to the Athens model and that of the NDRC is closer to the Berlin model, each with its own variations. ${ }^{12}$

The Pretoria model is a hybrid in another sense too. The tertiary landscape has changed dramatically over the past two decades, both internationally and nationally. To categorise these changes is out of the scope of this article. I therefore do not underestimate the influence of the Fourth Revolution on education, but would like to focus on just two aspects: the international academic arena of the 21st century and the sociopolitical changes in South Africa, especially after the so-called 'fallistic' Zeitgeist started with the \#Rhodesmustfall campaign in 2015. ${ }^{13}$ I will allude to these two aspects in the last section of this article, which deals with current issues under the sections 'Institutional competitiveness' and 'Transformation and decolonisation'.

In the second half of the 18th century, theological education started to develop its own nomenclature and was systematised as the so-called 'theological encyclopedia', in which Germany took the lead, in particular Schleiermacher's 'Brief Outline of Theological Studies' (Farley 2001:73). The aim was the academic challenge to assign different disciplines to a specific field of knowledge. Schleiermacher argued that religions do not rest on principles, revealed or otherwise. 'They rest on a kind of intuition or insightful experience, which can be the subject of philosophical inquiry' (Kelsey 1993:17). Schleiermacher reckoned that theology has three building blocks: historical theology, philosophical theology and practical theology (Schleiermacher 1850). By seeing practical theology as the 'normative field which critically apprehends the rules for carrying out the tasks of ministry' (Farley 2001:91), Schleiermacher guarantees theology a place at a research university, only for its 'professional' education. ${ }^{14}$

Farley (2001:85-94) acknowledges two aspects of Schleiermacher's contribution to theological education: the 'clerical paradigm' with its ideal (teleological solution) to

11.For a very thorough discussion of the place of a Theology of Religion(s) and the ordo duplex and ordo simplex, see Platvoet (1998).

12.It is noteworthy that a scholar of the NDRC has recently published an article where he argues that 'Scriptural reasoning attests to the way in which the faculty [i.e. of Pretoria] perceives its own identity' (Beyers 2018:1). The Faculty declared as its motto for the future, 'Gateway to ...' (inclusivity) and changed its name to the Faculty of Theology and Religion. By making the reading and interpretation of some ancient religious texts, the overlapping magisteria of inter-religious dialogue, Beyers clearly opts for a wissenschaftliche approach. Borg (2014: loc 954) says that he has learnt that there is conflict between the Bible and Jesus, between the Bible as the Word of God and Jesus as the word of God, which of course makes one wonder if Christianity should see texts as its basis.

13.For a rather good synopsis and analysis, see $\mathrm{https}$ //en.wikipedia.org/wiki/Rhodes Must Fall and https://africaisacountry.atavist.com/decolonizing-knowledge-and-thequestion-of-the-archive

14.Beyers (2018:3) shows a rather appreciative interpretation of Schleiermacher's hreefold distinction and elaborates on the basis of the vision and mission of th Faculty at Pretoria on how it could collaborate with other sciences and religions. unity and the 'essence of Christianity motif'. These aspects assure the discipline of theology with a single subject matter, though not pure science, but a positive science: 'the parts of which are connected into a whole, only by their common relation to a determinate mode of faith, that is, a determinate form of God-consciousness' (Schleiermacher 1850:91). The importance here is that there is a shift from knowledge itself to the reference of knowledge. This raises, according to Schleiermacher, the question of whether studying the Bible or Scripture as such could be a science. ${ }^{15}$

\section{Society and faith communities}

Tanner clearly sees the problem that critical theology (theological inquiry as I epitomise it) is under severe attack from critical scholars from other disciplines, mainly because of theology's methodology, its lack of objectivity and its disdainful disinterest in other disciplines' search for truth. The real issue is, of course, whether theology can contribute to the knowledge of our world and our place in it (Tanner 2002:200). Theology has therefore to reconceptualise both university and theology in order to establish its place. Tanner (2002:203-204) wants to see a 'constructive theology' that does justice to the interreligious and interdisciplinary character of a university. She makes the following important observation as well as an implicit challenge to address, 'Universal generalizations are made by each intellectual discipline while the whole of them remains a mere confederation, absent the need for consultation and correction by others' (Tanner 2002:204).

Disciplines that isolate themselves by decontextualising the world of human experience cannot survive and accountability has to be taken for who makes claims, in what context and for what purpose. A university will therefore always be a place of contestation, old and new, familiar and foreign, claims of understanding the world and our place in it. Tanner (2002) contends that constructive theology forms part of the cultural contest of the university:

In a search for truth humbled by the recognition of constant change and limitations of perspective, this cultural contest would require the widest possible purview, including in its reach the sort of ever-expanding range of positions that only the best critical scholarship makes readily available and that only a university dedicated to comprehensive knowledge can set easily in conversation with one another. (p. 206)

The university is the best location for contestable discourse, as Kaufman (1996:loc 2946) and Kelsey (2009:317) concur. Three reasons are provided: research resources, academic freedom and ongoing debates about knowledge, value, morality and meaning.

15.The Pretoria model currently has five departments, which are listed in another article (Buitendag 2016:8). During the final stage of the institutionalisation by the Senate of the five departments, the following question was raised by the executive: why Old Testament Studies and New Testament Studies could not merge ?. Both the respective heads of department opposed it and so did l. However, my argument was different. thinking in proleptic terms, I did not want to abolish the distinction between Abrahamic faiths based on the Old Testament and Christianity primarily based on the New Testament. In too many cases, the Old Testament is interpreted Christologically and compromises non-Christian scholars to study the text biasedly. 
Critical theology is not generic. It should be evident that the distinctiveness of the Christian, for example, contribution to the mix of cultural contests requires personal convictions and presuppositions that are unique in the debate (Kaufmann 1996:loc 2954). The cultural-linguistic approach of Lindbeck (1984), as opposed to cognitive and experiential-expressive approaches deserves serious consideration. This is a sort of pragmatic and pluralistic methodology to get along with diverse opinions and develops a theological language in its own right (see Tanner 2005:13), and over and above this, it 'involves a vis-à-vis with other intellectual and cultural fields' (Tanner 2002:210). Kaufmann (1996:loc 2969) warns that we 'need secularist and Marxist theologians as much as Christian and Muslim ones'.

Theological inquiry should not be exclusive 'Christian theology' in any traditional sense. The otherness of the other may never be suppressed. When too much emphasis is laid on referential adequacy and the decontextualisng of language, the whole discourse is being jeopardised (Tanner 2005:167). Theologians must pay attention to ways of thinking that are significantly different from those endorsed by their faith communities. ${ }^{16}$

Keith Ward, in Re-Thinking Christianity, devotes a chapter to critical faith and concludes with a rather provocative subsection: 'The value of disagreements in religion' (Ward 2007:123-124). Those who think differently from us cannot be regarded as malicious people who 'imperil the soul and corrupt the mind'. The best way to seek truth is to allow as many as possible different views. This is not a matter of being 'indifferent', but is a serious concern to hear opposing voices and to learn from them. Tolerance and intellectual humility are important scholarly virtues, firmly founded on one's own conviction and faith. Luhmann (1985) sees it correctly, when he states:

The old difference between sacred and profane, applied to places, occasions, persons etc., had to be replaced with a difference which could be handled as a purely internal difference within the religious system itself, representing, as it were, the difference between those included in and those excluded from the religious system. (p. 12)

According to Luhmann (2013:29), sociology, and not psychology or anthropology, is the most appropriate science of religion. Religion is, for him, embedded in and part of society and cannot be opposed to 'the social'. 'Societies are a special case of self-referential systems. They presuppose a network of communications, previous communications and further communications and also communications which happen elsewhere' (Luhmann 1985:6). Luhmann, being a genuine postmodernist, provides a constructivist sociology of contemporary world society.

16.It would be clear by now why I prefer the word 'faith-communities' to "church". The latter is simply too narrow and prejudiced with regard to one faith tradition or even a single denomination (ecclesiastical heteronomy). A socially constructed reality emerges from ongoing conversations among many different voices. Religious truth is contingent and transformed in unpredictable ways. 'Evolution is not a goalseeking process. Its causes are accidental; they are not appropriate means to produce a result. In other words, the evolution of religious forms and religious systems does not depend on religious causes, events, experiences (although the religious system will describe its own history in these terms)' (Luhmann 1985:10).
Religion is a field that Luhmann describes as an autonomous autopoietic subsystem of modern society. ${ }^{17}$ 'Autonomy is not independence. It is the self-referential circularity itself - not a desired state of being relatively independent from the environment but an existential necessity' (Luhmann 1985:7). This means that religion influences other social systems such as law, education or politics. Necessarily these also influence religion, although it remains the religious system's decision on how to acknowledge or describe them (or not). Rather than ignoring or explaining these away, I argue for a religious discourse that illuminates and accommodates these external social stimuli.

Luhmann (2013:1) subsequently introduces the theorem of double contingency at a basic level to analyse the emergence of social systems. Religion is a highly specific specimen of systems theory. Neither ontological nor analytical solutions are of any help nowadays. Religion cannot be understood adequately in terms of subject/object or observer/object binaries because it is located on both sides of the distinction between self - and other - reference (Luhmann 2013:5). Religion has always to include what it excludes.

I take the consequence of this to mean that religion has a unique role to play in social communication and should embrace this role by being self-conscious and self-reflexive in its awareness of the unique contribution it can make to scientific discourse while being receptive to the communications from other scholarly disciplines and systems.

\section{Institutional competitiveness}

Over the last two decades, the understanding of universities has totally changed. Major reconfigurations are happening all over the world and at all levels. Ford (2007:305) articulates the new challenge aptly, 'globalisation and commodification of higher education and advanced research'. Researchintensive universities have become businesses and are very much focused on their reputation. My argument has the presupposition that under 'university', I understand a specific niche university ${ }^{18}$ where international and national competitions form the driving force.

Today, research universities aim to improve their position on the ranking of world universities. This is a fairly new development because it dates back to the Chinese government's initiatives at the beginning of 21st century. Its aim was clearly to compete internationally and they took the

17. Nichizaka (1993:69) provides relevant background to understanding Luhmann's definition of religion: 'First, it succeeds in differentiating religion from other types of cultural ideas by relating the former to the dichotomy of transcendence and immanence, each of which is the negation of the other. Second, it in theory permits the existence of apparently destructive, but religious events, by leaving open what kind of form the ciphering process gives to the indeterminability of the world; i.e., by leaving open in what way the indeterminable is transformed into the determinable. Finally, it explicitly avoids defining religion with or as reference to the unexplicated concept of the sacred, by starting with inquiring into the constitution of meaning, or the presupposition of ordinary experiences.'

18.I previously distinguished at least three categories of universities (Buitendag 2016:5): Theological training is carried out by a church and is financially supported by the relevant denomination(s). Obviously, there is much emphasis on the praxis of the denomination and no critical thinking happens. Theological education is of a much higher standard, and such institutions are often accredited university status much higher standard, and such institutions are often accredited university status
by government. Theological inquiry is what this article is about and concentrates on research impact and education of professional clergy. 
lead to set the rules of ranking. The first ranking index was developed in 2003 and is known as the Shanghai Jiaotong Index. Three other globally acknowledged instruments have been designed since then: the Academic Ranking of World Universities (ARWU), the Times Higher Education World University Ranking (THE) and the Quacqaurelli Symonds World University Ranking (QS-WUR). In most of these cases, most weight is placed on impact research in the natural sciences, and journals like Nature and Science are explicitly acknowledged as the benchmark for journals of the world. ${ }^{19}$ (Buitendag 2014:3).

This last aspect (QS-WUR), of course, makes it extremely difficult for theology to contribute to institutional goals, especially research impact and even fundraising. Elsewhere, we (Buitendag \& Simuț 2017a) have argued extensively that the current indices are inadequate for measuring the performance of theology as the models are primarily designed for natural sciences and the impact factors of the research conducted in the natural sciences exceed that of theology substantially. Yet, I am of the opinion that a faculty of theology and religion not only can but also should contribute to a university's ranking. Of utmost importance is the producing of doctoral degrees ${ }^{20}$ and the generating of citations (not only publishing) in journals indexed by Scopus, Web of Science's (WoS) Institute for Scientific Information (ISI), the International Bibliography of the Social Sciences (IBSS), the Norwegian List and even SciELO SA.

It is only the QS-WUR ${ }^{21}$ index that makes provision for the subject of 'theology, divinity and religious studies', while the THE index regards this category as part of Philosophy and therefore Humanities. An analysis of these statistics of the QS ranking list of theological inquiry indicates the comparison between the different positions at the respective institutions. Only the first 50 are prioritised and the others between 51 and 100 are arranged alphabetically. No ranking of subject fields is done beyond $100 \mathrm{th}^{22}$ and for institutions beyond the 500th position.

\section{Transformation and decolonisation}

Theology in South Africa, as most other things, has been driven by apartheid ideologies that caused a deep divide and a subsequent heterogeneous landscape. ${ }^{23}$ Naidoo (2016:3) pleads for 'an approach that takes on a diversity of perspectives

19.For the different criteria that respective indexes apply, see my article (Buitendag 2016:6)

20.Cloete, Maasen and Bailey (2015:282) mention the importance of lecturing staff to obtain PhDs themselves for bettering rating positions.

21.See https://www.topuniversities.com/university-rankings/university-subjectrankings/2019/theology-divinity-religious-studies

22.The 2019 list has only two South African universities on the top 100 list with regard to theology, as being between 50 and 100, which are Stellenbosch University and the University of Pretoria. In terms of citations per paper and $h$-index citations, the Faculty at Pretoria takes the lead. The previous year there were four universities from the African continent listed, but the American University in Cairo and the University of KwaZulu-Natal lost their positions on the latest ranking.

23.For a thorough overview of theological education in Africa, see Phiri and Werner (2013). of cultural, public and Christian life, with Africanisation representing one of these "other" perspectives'. ${ }^{24}$

The technical term to address this is 'decolonisation'. Many scholars from developing countries are opposing Western models vehemently. The following citation of Alvares and Faruqi (2012) suffices to get the gist of it, and even an underlying wrath:

A more recent form of Western hegemony is the yearly university ranking lists. Western education, Western science and Western achievements are subjected to evaluation on criteria that are rigged in their favour ... The book's ultimate aim is to discover what needs to be done to liberate our minds and our souls; to end this academic colonialism; to restore our dignity and independence. We must shed the slavish mentality of blindly aping Western paradigms. (p. 14)

Govinder, Zondo and Makgoba (2013:86) published an article stating the pace is 'painfully slow' to eradicate racism and sexism in the demographic transformation of universities in South Africa. They refer to the disjunction between policy and real-life experiences, and the need for a new institutional landscape that is 'responsive and contributes to the human resource and knowledge needs of South Africa'.

Heleta (2016:5) is clear about the fact that decolonisation will not lead to localisation, isolation or only Africanisation of the curriculum. 'Decolonised curriculum will not neglect other knowledge systems and global context. Universities still have to develop globally competent graduates capable of functioning in the complex and connected world' (Heleta 2016:5). This can only be done by challenging existing truths and to deconstruct existing epistemologies. The public space as a whole has to be rehabilitated.

During a public lecture given at the Wits Institute for Social and Economic Research (WISER) in conversations with the Rhodes Must Fall Movement, Achille Mbembe delineates the true character of decolonisation:

An event that could radically redefine native being and open it up to the possibility of becoming a human form rather than a thing;

An historical event in the sense that it could radically redefine native time as the permanent possibility of the emergence of the not yet.

To the colonial framework of pre-determination, decolonization opposes the framework of possibility - possibility of a different type of being, a different type of time, a different type of creation, different forms of life, a different humanity - the possibility to reconstitute the human after humanism's complicity with colonial racism. ${ }^{25}$ (Mbembe, n.d.)

24.In the seminal work of Cloete et al. (2015:12) though, they see the challenge for African universities to decouple from the nation's socio-economic development and to pursue ways to engage in development and innovation networks. 'Researchrooted information' is what the Higher Education Research and Advocacy Network in Africa (HERANA) project was initiated by the Centre for Higher Education Transformation (CHET) in 2007. The project seeks to connect universities with economic and democratic development. The HERANA project, funded mainly by the Carnegie Corporation of New York and the Ford Foundation, comprises a network of about 50 academics and practitioners from around the world.

25.See https://africaisacountry.atavist.com/decolonizing-knowledge-and-thequestion-of-the-archive. 
Sensible appropriation of decolonisation is imperative. The Faculty has decided on an overarching project, called Ecodomy, to promote Africanisation of the curricula. This is a process of continuous adaptation of the Faculty to current challenges in society without ignoring the basics. Perhaps a sort of aggiornamento.

\section{Conclusion: A definition and a vista}

The context of a university and the contexts from which it draws its students need to co-determine the nature of its curricular content (cf. Buitendag \& Simuț 2017b). De Beer and Van Niekerk (2017) articulate it correctly when they assert:

The challenge therefore is to shape theological curricula that could significantly contribute to the freedom and well-being of societies by presenting spaces for rigorous and critical engagement, hosting not only similarity but particularly diversity, hosting different traditions and even religious expressions and hosting contesting voices in order to become not only places of freedom and life but also what Parker Palmer speaks of as 'a community of truth' which is 'a web of communal relationships' committed to learn together. (p. 216)

I owe much to the Durban Declaration of the second Higher Education Summit on transformation during October 2015 in Durban (DHET 2015), in my definition of what a public university should be in the 21st century, especially in Africa. I augmented it by adding Kofi Anan's view, who wants to see that universities become agents of change and 'the critical source of equalisation of chances and democratisation of society by making possible equal opportunities for people' (quoted in Cloete, Maasen \& Bailey 2015:12). The distinguished reader will notice that my move towards a meta-space adds a further component, and therefore acknowledgement to paideia. Here is therefore my understanding of the type of university under discussion:

Public universities are places of contestation and agents of change in order to provide spaces for creating knowledge, freedom of thought, vistas for the future and to provide wellrounded citizens to society.

Cheryl de la Rey, former vice-chancellor and principal of the University of Pretoria (2009-2018), is on record when she said 'that the university's main business is human capital development' (Makholwa 2014:21).

Ford (1997:723) asks how hospitable academic institutions would be to a faculty of theology in the future. In the end, this is the crucial question and the word 'hospitable' is thus rather laden. This depends, in my view (Buitendag 2014:5), upon:

- the scholarly contribution theology can make as an important perspective on understanding reality

- the extent to which it can be methodologically accountable

- the openness and resilience it shows to immanent criticism

- the fidelity asserted to its subject matter as the science of God

- the values it reflects and the social cohesion it inaugurates in society

- the idea of a university.
Hospitality is determined and executed by people, and Smart (Fasching 2002:156) is thus correct in saying that the specific institutional context plays a decisive role in defining intellectual activity and recognition. Only four out of the original 11 faculties of theology in South Africa still exist as actual faculties, acknowledging theology's unique nature and epistemology. However, it remains the prerogative of the executive of the institution to 'tick the boxes' of the first five points above and the determination of their idea of a university, at least for its own institution's purposes. ${ }^{26}$

Therefore, I would like to list the alternatives that could exist for the Faculty of Theology and Religion pertaining to its future at the University of Pretoria. Obviously, the Faculty has to internalise the above-mentioned criteria and to execute its current mission vehemently. The alternatives for future deliberations in my view are subsequently the following:

1. The Faculty maintains its acknowledgement as a proper faculty with a distinctive epistemology (theological inquiry, faith-based, and not Christian per $s e^{27}$ ), cooperating and contributing to the endeavour of all sciences to comprehend reality somehow. This requires constructive engagement with 'the other' (i.e. society, faith communions, sciences, religions and different forms of nihilism) and should engage as an alienated theology, free from ecclesiastical heteronomy.

2. The Faculty is absorbed by another faculty, and as has already been pointed out, Humanities is not necessarily the obvious locus because of its (secular) epistemologies and scholarly autonomy. The Faculty of Education would be a sound alternative in terms of the Berlin model with its other pole of professional education. As a niche department (I would prefer school), it would be possible to maintain theology's distinctiveness and obviously its professional formation and community engagement. The cooperation of ecclesial and societal partners is a sine qua non for this option.

3. Most of the present ecclesial stakeholders of the Faculty have their own complementary training, which focuses on the induction of their ministers-to-be and the reinforcement of a specific denominational ethos. This is an ideal situation as long as it plays an ancillary role, but the moment when the ecclesial partnership develops into an alternative or a substituting body and a seminary emerges, theological inquiry and alienated theology would be relinquished. This choice of course depends upon the different churches and therefore does not lie within the scope of this reflection. This would nevertheless mean the end of the Faculty of Theology and Religion in its present form at the University of Pretoria.

4. Should the Faculty reach a stage that it is no longer financially and administratively sustainable primarily because of a lack of student numbers (especially postgraduate students),

26.Farley (1988:40-42) warns against the tendency of quantitative sciences setting the paradigm for study and research and when it becomes ontological (a paradigm of reality itself), it is impoverishing knowledge and manifests as a belief.

27.Krüger (2017:1) in his analysis of the restructuring of the Faculty and its centenary strapline wants to put the emphasis on opening of 'the gates' for other religions at the Faculty. 'An open forum out there where Christians, Jews, Muslims, non-theists (the issues concerning the meaning of human existence on planet Earth. Yet I submit that such a new leg of the faculty will have an impact on the manner of moving of the first leg and the way of walking of the faculty as a whole'. 
institutional funding and ecclesial support, there should be at least a department (not school this time) of religion (not religious studies ${ }^{28}$ ) in the Humanities, with an emphasis on the Wissenschaftlichkeit of the Berlin model, without Schleiermacher's other pole of professional education, and on 'metaphysical mysticism' of a metareality, characterised by a faith-based approach. ${ }^{29}$

During the centenary year of the Faculty of Theology and Religion at the University of Pretoria, the university conferred on 06 April 2017 an honorary doctorate degree (Doctor Divinitatis h.c.) on Prof. Jürgen Moltmann. On Monday (03 April 2017) prior to the graduation occasion, I had the privilege to introduce Prof. Moltmann to the then ViceChancellor and Principal of the University, Prof. C.M. de la Rey, in her office. One of the very first questions after we had sat down she posed to him was the following: Prof. Moltmann, what do you think is the future of (a faculty of) theology at a public university? He pondered a while and then he responded forcefully: 'As long as truth $^{30}$ is important to a university, there is a place for theology'.

\section{Acknowledgements Competing interests}

The author declares that he has no financial or personal relationship(s) that may have inappropriately influenced him in writing this article.

\section{References}

Alston, W.P., 1991, Perceiving God. The Epistemology of religious experience, Cornell University Press, Ithaca, NY.

Alvares, C. \& Faruqi, S.S., 2012, Paradigms, decolonizing the University. The emerging quest for non-eurocentric paradigms, Penerbit Universiti Sains Malaysia, Pulau Penang.

Beyers, J., 2018, 'Scriptural reasoning: An expression of what it means to be a Faculty of Theology and Religion', HTS Teologiese Studies/Theological Studies 74(4), 5048. https://doi.org/10.4102/hts.v74i4.5048

Borg, M., 2014, Convictions. How I learned what matters most, Kindle edn. HarperOne, New York.

Bowker, J., 2003, God. A brief History, Dorling Kingsley Limited, London.

Buitendag, J., 2014, 'Between the Scylla and the Charybdis: Theological education in the 21st century in Africa', HTS Teologiese Studies/Theological Studies 70(1), 5. https://doi.org/10.4102/hts.v70i1.2855.

Buitendag, J., 2016, “"The idea of the University" and the "Pretoria Model" Apologia pro statu Facultatis Theologicae Universitatis Pretoriensis ad secundum saeculum', HTS Teologiese Studies/Theological Studies 72(4), 11. https://doi.org/10.4102/hts. v72i4.4366

Buitendag, J. \& Simuț, C., 2017a, 'Rethinking research impact by Theology and religious studies with references to the Faculty of Theology at the University of Pretoria', Verbum et Ecclesia 38(4), 3-33. https://doi.org/10.4102/ve.v38i4.1743

Buitendag, J. \& Simuț, C., 2017b, 'Teaching theology at African public universities as decolonisation through education and contextualisation', HTS Teologiese Studies/ Theological Studies 73(1), 8. https://doi.org/10.4102/hts.v73i1.4806

Cloete, N., Maasen, P. \& Bailey, T., 2015, Knowledge production and contradictory functions in African Higher Education, vol. 1, African Minds, Somerset West, African Minds Higher Education Dynamics Series 1.

De Beer, S.F. \& Van Niekerk, A.S., 2017, 'Transforming curricula into the next century: Doing theology collaboratively with local communities', Verbum et Ecclesia 38(4), a1683. https://doi.org/10.4102/ve.v38i4.1683

28.See footnote 2 .

29. Krüger (2016:12) is of the opinion that seeds of such a vista are established in the archaeology and genealogy of the Faculty: 'In this connection the existential style of doing theology in the NRCA remains a promising resource, as the mystical tradition in the DRC tradition'. The African religious mind fits this model extremely well.

30.Elsewhere, Moltmann (1980:12) describes his view of truth: 'Dahinter steht die Überzeugung, dasz Wahrheit sich menschlich gesehen im unbehinderten Dialog ereignet. Gemeinschaft und Freihet sind die menschliche Komponente für die Erkenntnis der Wahrheit'.
Department of Higher Education and Training (DHET), 2015, The 2015 Durban Statement on Transformation in Higher Education, 2015, Department of Higher Education and Training, Pretoria.

Farley, E., 1988, The fragility of knowledge. Theological education in the Church and the University, Fortress Press, Philadelphia, PA.

Farley, E., 2001, Theologia. The fragmentation and unity of theological education, Wipf and Stock Publishers, Eugene, OR.

Fasching, D.J., 2002, 'Religious studies and Alienation of Theology', in L.E. Cady \& D. Brown (eds.), Religious studies, theology, and the university. Conflicting maps, changing terrain, pp. 155-171, State University of New York Press, New York.

Ford, D.F., 1997, 'Christian theology at the turn of the millennium', in D.F. Ford (ed.) The modern theologians, pp. 720-728, 2nd edn., Blackwell Publishers, Oxford.

Ford, D.F., 2007, Christian wisdom. Desiring God and learning love, Cambridge University Press, Cambridge.

Govinder, K.S., Zondo, N.P. \& Makgoba, M.W., 2013, 'A new look at demographic transformation tor universities in South Africa', South African Journal of Science 109(11/12), Art. \#2013-0163, 11. https://doi.org/10.1590/sajs.2013/20130163

Heleta, S., 2016, 'Decolonisation of higher education: Dismantling epistemic violence and Eurocentrism in South Africa', Transformation in Higher Education 1(1), a9. https://doi.org/10.4102/the.v1i1.9

Jansen, J., 2009, Knowledge in the blood. Confronting race and the apartheid past, UCT Press, Cape Town.

Kaufman, G.D., 1996, God - Mystery - Diversity. Christian Theology in a Pluralistic World, Kindle edn., Fortress Press, Minneapolis, MN.

Kelsey, D.H., 1992, To understand God truly. What's theological about a theological school?, Westminster/John Knox Press, Louisville, KN.

Kelsey, D.H., 1993, Between Athens \& Berlin. The theological education debate, Wipf \& Stock, Eugene, OR

Kelsey, D.H., 2009, 'Theology in the university: Once more, with feeling', Modern Theology 25(2), 315-327. https://doi.org/10.1111/j.1468-0025.2008.01521.x

Krüger, J.S., 2016, 'The study of religion and theology at the University of Pretoria - A century of endeavour in conditionalistic perspective', HTS Teologiese Studies/ century of endeavour in conditionalistic perspective', HTS Teologiel
Theological Studies $72(4)$. https://doi.org/10.4102/hts.v72i4.3575

Krüger, J.S., 2017, 'The study of theology and religion at the University of Pretoria: Two epochs of endeavour', HTS Teologiese Studies/Theological Studies 73(1), a4615. https://doi.org/10.4102/hts.v73i1.4615

Lindbeck, G.A., 1984, The nature of Doctrine. Religion and theology in a postlibera age, The Westminster Press, Philadelphia, PA.

Luhmann, N., 1985, 'Meaning, religion: Based on self-reference', Sociological Analysis 46(1), 5-20. https://doi.org/10.2307/3710892

Luhmann, N., 2013, A system theory of religion, Stanford University Press, Stanford, CA.

Makholwa, A., 2014, 'Race to the top', Financial Mail, 24 January, pp. 16-22.

Mbembe, A., n.d., Decolonizing knowledge and the question of the archive, viewed 18 March 2019, from https://africaisacountry.atavist.com/decolonizing-knowledgeand-the-question-of-the-archive.

Milbank, J., 2013, Beyond secular order. The representation of being and the representation of the people, 1st edn., Wiley Blackwell, Chichester.

Moltmann, J., 1980, Trinität und Reich Gottes. Zur Gotteslehre, Chr. Kaizer Verlag, München.

Moltmann, J., 2003, Science and wisdom, Fortress Press, Minneapolis, MN.

Naidoo, M., 2016, 'Overcoming alienation in Africanising theological education', HTS Teologiese Studies/Theological Studies 72(1), 8. https://doi.org/10.4102/hts. v72i1.3062

Nichizaka, A., 1993, 'Religious faith as communication practise', International Journa of Japanese Sociology (IJJS) 65-78. https://doi.org/10.1111/j.1475-6781.1993. tb00017.x

Niebuhr, H.R., Williams, D.D. \& Gustafson, J.M., 1956, The purpose of the church and its ministry, Harper \& Row, New York, viewed n.d., from file:///G:/My\%20Drive/ Navorsing/Uni\%20\&\%20Faculty/Niebuhr\%20The \%20ldea \%20of\%20a\%20 Theological $\% 20$ School $\% 20 \%$ E2\%80\%93\%20Religion\%200nline.html.

Phiri, I.A. \& Werner, D. (eds.), 2013, Handbook of theological education in Africa, Cluster Publications, Dorpspruit.

Platvoet, J.G., 1998, 'Close harmonies: The Science of Religion in Dutch Duplex Ordo Theology, 1860-1960', NUMEN 45, 115-162. https://doi.org/10.1163/156852798 1588359

Schleiermacher, F.D.E., 1850, Brief Outline of the Study of Theology, viewed 07 March 2019, from https://books. google.co.za/books?id=WHORAAAAYAAJ\& printsec=fron tcover\&source=gbs_ge_summary_r\&cad=0\#v=onepage\&q\&f=false

Schleiermacher, F., 1999, The Christian faith, T \& T Clark Ltd., London.

Tanner, K., 2002, 'Theology and cultural contest in the University', in Religious studies, Theology, and the University. Conflicting maps, Changing Terrain, pp. 199-212, State University of New York Press, New York.

Tanner, K., 2005, God and creation in Christian Theology, Fortress Press, Minneapolis, MN.

Tillich, P., 1946, 'Religion and secular culture', The Journal of Religion 26(2), 79-86. https://doi.org/10.1086/483442

Venter, R. \& Tolmie, F., 2012, Transforming theological knowledge: Essays on theology and the university after apartheid, Sun Media, Bloemfontein.

Ward, K., 2007, Re-thinking Christianity, Oneworld Publications, Oxford. 